\title{
MODELLING THE IMPACT OF MINING ON SOCIO-ECONOMIC INFRASTRUCTURE DEVELOPMENT - A SYSTEM DYNAMICS APPROACH
}

\author{
G.T. Maluleke ${ }^{1 \#} \&$ L. Pretorius ${ }^{1 *}$
}

\section{ARTICLE INFO}

\section{Article details}

Submitted by authors 23 Jan 2015

Accepted for publication 1 Sep 2016

Available online 6 Dec 2016

\section{Contact details}

* Corresponding author

leon.pretorius@up.ac.za

Author affiliations

1 Department of Engineering and Technology Management, University of Pretoria, South Africa

\# The author was enrolled for a PhD in the Department of Engineering and Technology Management, Graduate School of Technology Management at the University of Pretoria, South Africa

DOI

http://dx.doi.org/10.7166/27-4-1133
ABSTRACT

The contribution of mining activities to social infrastructure and human development is a complex socio-economic development issue in South Africa. Complexity theory has introduced a new approach to solving problems in social systems, recognising them as complex systems. The socio-economic development system in South Africa falls into this category of complex systems. Analysing such a system requires that a number of feedback loops and details about the issues be analysed simultaneously. This level of complexity is above a human's ability to comprehend without the aid of tools such as systems thinking and system dynamics. The causality between investment in infrastructure capacity and socio-economic development is dynamic. The relationship is influenced by exogenous feedback that, if not managed, is likely to reverse itself. This paper presents the results of a system dynamics modelling of the relationship, based on the principle of relative attractiveness developed in previous system dynamics research. A Monte Carlo analysis is used to determine the sensitivity of the system to changes in feedback. The paper concludes that the limits to growth in a socio-economic environment are determined by more factors than the availability of capital, and also include land capacity constraints and skills shortage.

\section{OPSOMMING}

Die bydrae van mynbou-aktiwiteite tot sosiale infrastruktuur en menslike ontwikkeling is 'n komplekse sosio-ekonomiese ontwikkeling kwessie in Suid-Afrika. Die kompleksiteitsteorie het ' $n$ nuwe benadering tot die oplossing van probleme in sosiale stelsels gebring deur hulle as komplekse stelsels te benader en die sosioekonomiese ontwikkeling in Suid-Afrika val binne hierdie kategorie van komplekse stelsels. Die ontleding van so 'n stelsel vereis dat 'n aantal terugvoerlusse en besonderhede rondom die kwessies gelyktydig ontleed word. Hierdie vlak van kompleksiteit is bo menslike vermoë om te verstaan sonder die hulp van gereedskap soos stelsel denke en -dinamika. Die verwantskap tussen belegging in kapasiteit infrastruktuur en sosio-ekonomiese ontwikkeling is dinamies. Die verwantskap word beïnvloed deur eksterne terugvoer, en indien dit nie bestuur word nie is die verwantskap geneig om ook in die omgekeerde rigting neerslag te vind. Die artikel bied die resultate van ' $n$ dinamiese stelsels-modellering van die verwantskap wat gebaseer is op die beginsel van relatiewe aantreklikheid en wat ontwikkel is vanuit vorige stelseldinamika navorsing. ' $n$ Monte Carlo analise word gebruik om die sensitiwiteit van die stelsel ten opsigte van verandering in terugvoer te bepaal. Een van die gevolgtrekkings in die navorsing is dat die grense van groei in 'n sosio-ekonomiese omgewing bepaal word deur meer faktore as die beskikbaarheid van kapitaal, wat die land kapasiteitsbeperkings en vaardigheidstekorte ook insluit. 
The Northern Cape Province is home to 80 per cent of the world's known manganese reserves and a significant deposit of iron ore reserves [31]. The province also hosts a considerable number of saltpans [8], and is one of the areas of highest sun radiation in South Africa [22]. Iron ore and manganese are pivotal inputs to steel manufacturing and infrastructure development, and have a mutually inclusive relationship [1]. This paper focuses on the impact of manganese mining activities on infrastructure capacity development and how this can influence the socio-economic conditions of the area where these activities occur. Esfahani et al. [8] conclude that the impact of infrastructure on GDP growth can be substantial.

It is suggested in this paper that a systems approach be undertaken to analyse the impact of mining activity on the socio-economic conditions of an area. Kramer et al. [18] define a system as a set of interrelated entities of which no subset is unrelated to any other subset. Weinberg [37] more recently defined a system as a way of looking at the world. He argues that it is the purpose of the system that gives it its right to exist. The socio-economic system today is fragile, interconnected, and more complex than it was in the past [31]. An insight into the manganese value chain and the beneficiation process is considered relevant to the analysis in this paper.

\subsection{Mining and minerals contribution to the economic activities}

Manganese is among the four most strategic minerals in South Africa (SA) mainly, in part, due to its application in the steel-making process as a metallurgical alloy [25]. Prices of sinter and ferromanganese represent 20 per cent and 40 per cent improvement respectively on the price of manganese ores, due to the enhanced manganese content through these two processes [26]. The challenge, however, is that mineral deposits tend to be located in large sparsely-populated areas with little integration into economic and political systems [5]. The graph in Figure 1 highlights the demand pattern of manganese in relation to iron and steel products, which demonstrates a significant causality amongst them.

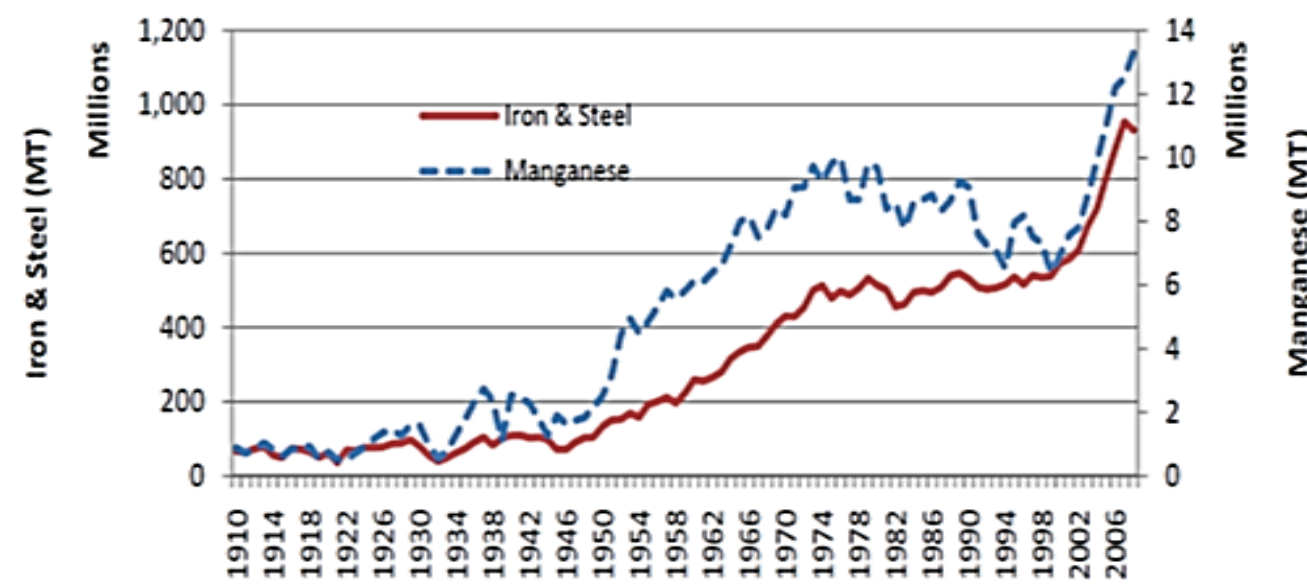

Figure 1: Iron ore, manganese, and steel production patterns [32]

\subsection{Iron ore and manganese mineral revenue patterns}

The graphs in Figure 2 depict the price patterns of a selected number of minerals, showing the superior growth of iron ore compared with other minerals, confirming its status as a strategic mineral [35]. Due to their common application in the production of steel products, the demand and final application of manganese and iron ore are linked [31]. 


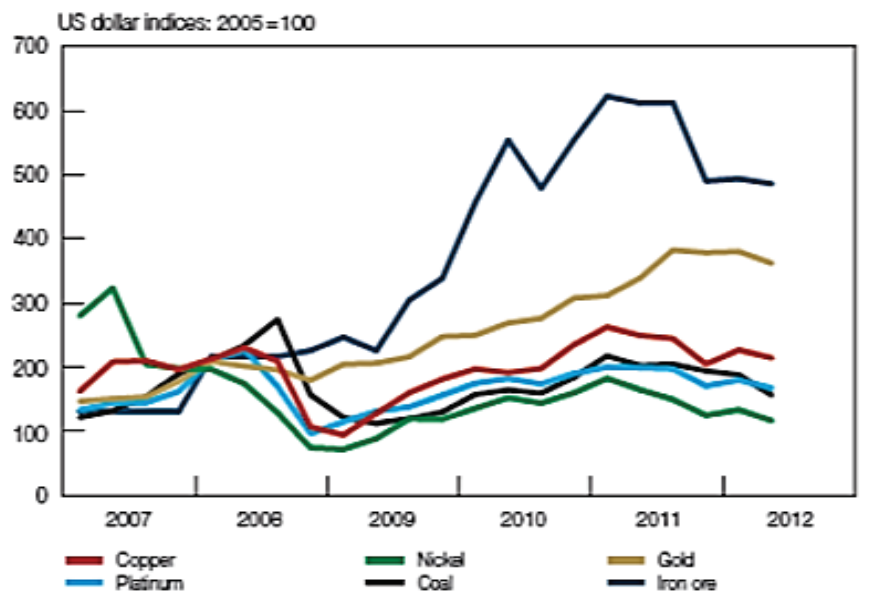

Figure 2: Mineral price patterns between 2007 and 2012 [32]

The superior performance of iron ore among the minerals in Figure 2 highlights the economic opportunity presented by the dependency of steel production on both manganese and iron ore.

\subsection{Objective of this paper}

The objective of this paper was to describe the causal relationship between choices made in the mining industry value chain and the impact such choices have on a socio-economic development system in the John Taolo Gaetsewe (JTG) region of South Africa. The research sought to describe a system level relationship between economic infrastructure, mining activities, and community social development in relation to sustainable development in a mining-driven economy. The basis for these relationships has already been indicated to some extent in sections 1.1 and 1.2.

In studying the behaviour of the socio-economic system within a mining-driven socio-economic system, the principle of relative attractiveness is applied in this paper. The principle of relative attractiveness was first applied by Forrester [11] in the urban dynamics work; however, this principle has been used by later scholars including O'Regan [24] and Saeed [30]. This research has applied the principle of relative attractiveness to establish the impact of changes in mining and socio-economic infrastructure dynamics on the pattern of socio-economic development in the JTG region. These principles have also been introduced in the research methodology followed in this paper, and are described in the next section.

\section{RESEARCH METHODOLOGY}

The research mainly follows a simulation-based approach, complementing an empirical form of research. This is achieved through inference of relationships between variables by analysing new data created from programmes [17] to create knowledge about the system structure and its performance. Action research data is collected and synthesised through simulation to create new data and information about the system's behaviour. A system dynamics model is used to design and describe the dynamic behaviour of the system based on established mining processes, including the consumption of key input elements such as logistics and power. A Monte Carlo analysis tool, built into the system dynamics model software on the Vensim [36] platform, is used to perform the sensitivity analysis of the system towards changes in the exogenous feedback to the system.

\subsection{System dynamics modelling paradigm}

A significant advantage of using system dynamics models is that the approach helps policy makers learn what an endogenous view is, and why it is necessary for effective policy-making or objectivesetting [9]. As Sterman [34] correctly points out, the challenge for humans in solving complex problems such as those represented in the mining case discussed in this paper lies in the cognitive and informational limitations in human beings, which affects their rationality. It is important to understand the crucial elements of a system (reinforcing, balancing, and delay) prior to undertaking 
the system dynamics modelling exercise on a system. Peter Senge [33] refers to circles of causality between crucial elements and their importance in solving complex problems.

Forrester [10] also concludes that there is greater possibility that participants in system dynamics modelling may experience changes to their own mental models. Repenning [28] concludes that system dynamics is uniquely suited to tying all the non-linear elements of the social system together into an empowering social system. Forrester [10] argues that, in order to model the dynamic behaviour of a system, four hierarchies of structure should be recognised. These are: 1) the closed boundary around the system, 2) feedback loops as elements within the structure of the system, 3) state variables representing accumulations within the feedback loops, and finally 4) flow variables representing activity within the feedback loops. These elements of systems modelling have also been introduced into the current case of the manganese industry in SA.

\subsection{Research method}

The research was conducted within the boundary of the manganese industry in South Africa, with specific focus on the Kalahari basin around the JTG region. The system of interest for the research was defined as a collection of both manganese mining and the social-economic infrastructure within the JTG region. A system dynamics model comprising these two subsystems was created using a selection of key variables as 'flows' and sub-processes as 'stocks'.

The simulation approach adopted here agrees with the finding of Davis et al. [5] that the exploration and elaboration of simple theories can be achieved through simulation. Davis et al. [5] also found that simulation was central to the implementation, verification, and validation of the theory developed in research. Harrison et al. [15] point out in their work that simulation models provide logical consistency that is useful in theory development.

The simulation results presented in this paper focus on a defined system boundary, shown in Figure 3. The simulation parameters are derived from level 3 elements, as shown in the figure, and these constitute the endogenous variables for the model.

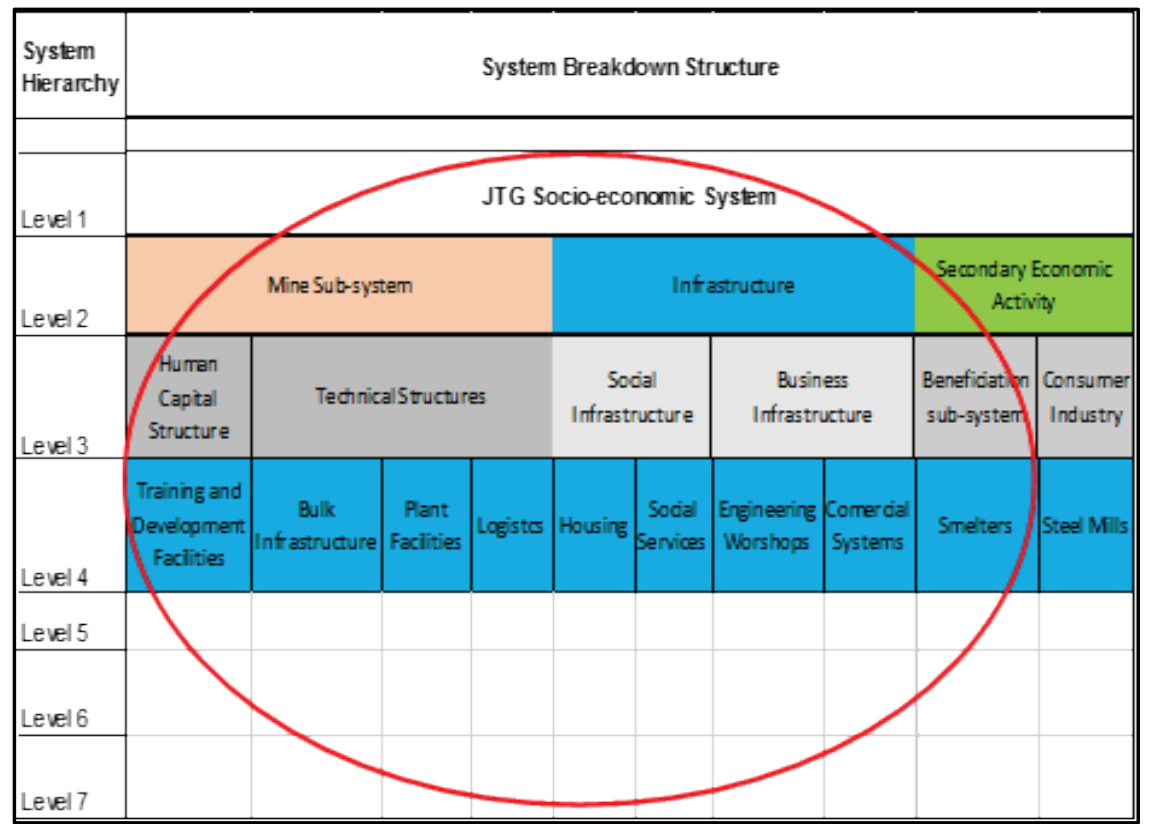

Figure 3: System boundary for the socio-economic system

The hypothesis tested through the system dynamics simulation was based on two statements: first, the finding of Perkins et al. [25] that there is a causal relationship between infrastructure development and economic growth; and second, the assertion of the Minerals and Petroleum Resources Development Act No. 28 of 2002 [6] that the beneficiation of minerals will increase employment opportunities. 


\subsection{Research process}

An exploratory study is described by Meyer et al. [20] as the first step in a research programme designed to develop a new theory or model that has broad applicability, or is at least generalisable beyond the research setting. The research process followed in this paper is exploratory, and represents a systems approach from problem identification through to system design and simulation.

In systems that comprise many interacting feedback loops and long time delays, causes of an observed symptom may come from an entirely different part of the system and lie far back in time [13]. Complexity can easily undermine confidence and responsibility, as in the frequent refrain, "It's all too complex for me", or "There's nothing I can do, it's a system" [37]. The aim of the systems approach followed in this research is to get a handle on the complexity represented by the manganese mining case study.

A system dynamics model based on the causal loop was designed and subjected to simulation of the system using the Vensim [36] platform. The simulation assumed a 10-year performance period ranging from 2006 to 2016 for the manganese mining case study. The result of the simulation was verified and validated, based on system dynamics methods.

Kleijnen [17] described verification simply as determining that a simulation computer program performs as intended. Referencing Forrester [10], Barlas [3] emphasises the relationship between the model's scientific validity and validity due to the usefulness of its purpose. This implies that the validity of the model has to consider the structural validity and the usefulness of the model, based on the questions raised and its similarity to other systems.

\section{SYSTEM DYNAMICS MODEL DESIGN AND SIMULATION}

The socio-economic development system is described as a set of entities that (for the case addressed in this paper) include: a mining activity, and economic and social infrastructure (housing development in particular), also referred to as socio-economic infrastructure. The representation of mining activity is limited to the manganese industry in the JTG region. The focus of the system dynamics modelling and simulation is on the impact of mining activity, from the point of view of what could be achieved with revenues generated from mining, and not the dynamics of the mining process itself.

Related to this discussion, in his work on modelling the managerial behaviour of such a socioeconomic system, Sterman [34] points out that the efficacy and decision strategies lie crucially in the action between decisions and changes in the environment that condition future decisions. As Barile [2] points out, in a holistic vision, time and space unite in a single whole, evading the perceptions of human beings.

\subsection{Principles and concepts adopted in the research}

Oliva [23] describes a dynamic hypothesis $(\mathrm{DH})$ as the theory that explicitly articulates how structure and decision policies generate behaviour. This research used causal loops - illustrated in Figure 4 to define the structure that articulates the behaviour of a socio-economic system in a mineralsdriven economic system.

In developing the causality diagram in Figure 4, a four-step approach advocated by Roos [29] that is based on comparison (with other situations), consequences (implications for decisions), connections (how a bit of knowledge or parameter links to others), and conversations (what other stakeholders think about the information) was used. This approach to gathering case information leads, for example, to the reinforcing Loop 2 in Figure 4, where an increase in 'industrial development' leads to more 'ability to sell more goods'. This, in turn, might lead to an increase in market demand for goods (manganese ore). This might then lead to increased rail and infrastructure development, finally returning to increasing industrial development. 


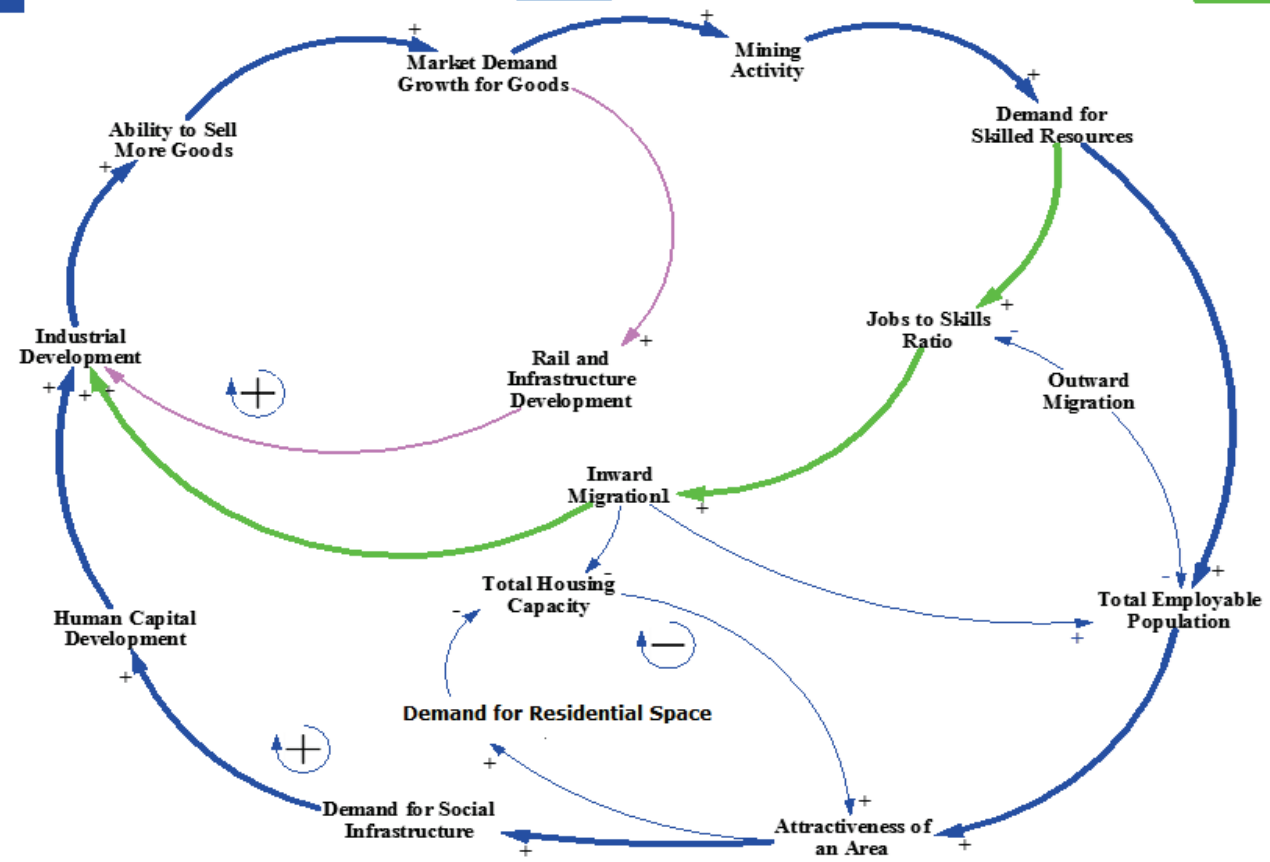

Figure 4: Causality loop diagram for the manganese-driven socio-economic system

This process of model development through dynamic hypotheses was guided by the systems thinking theory described by various scholars, among them Peter Senge [33], Cabrera et al, [4], Aronson [1], Roos [29], and Weinberg [37]. Cabrera et al. [4] correctly highlight that systems thinking can act as a bridge that provides feedback between 'what we know' about systems (e.g., systems science) and the conceptual patterns of 'how we think' systemically (e.g., systems thinking). Aronson [1] also affirms the value of systems thinking in complex problems that involve helping many actors see the 'big picture' and not just their part in it.

\subsection{Basis for the system dynamics modelling}

Franklin [13] defines simulation as an imitation of some real device or state of affairs, and that it attempts to represent certain features of the behaviour of a physical or abstract system by the behaviour of another system. This simulation approach has also been followed in this research.

The stock flow model diagram in Figure 5 is an extraction of a section from the socio-economic system dynamics model logic for the more detailed manganese mining system dynamics model discussed in the work of Maluleke [19]. This section of the model depicts the causal relationship between infrastructure development, mining activities, and the impact on the attractiveness of an area for business activities. The system dynamics model uses the principle of relative attractiveness of the area under simulation as a moderator of infrastructure development, by acknowledging that infrastructure growth requires other factors, such as availability of suitable land and a skilled workforce, to have the requisite impact on economic development. 


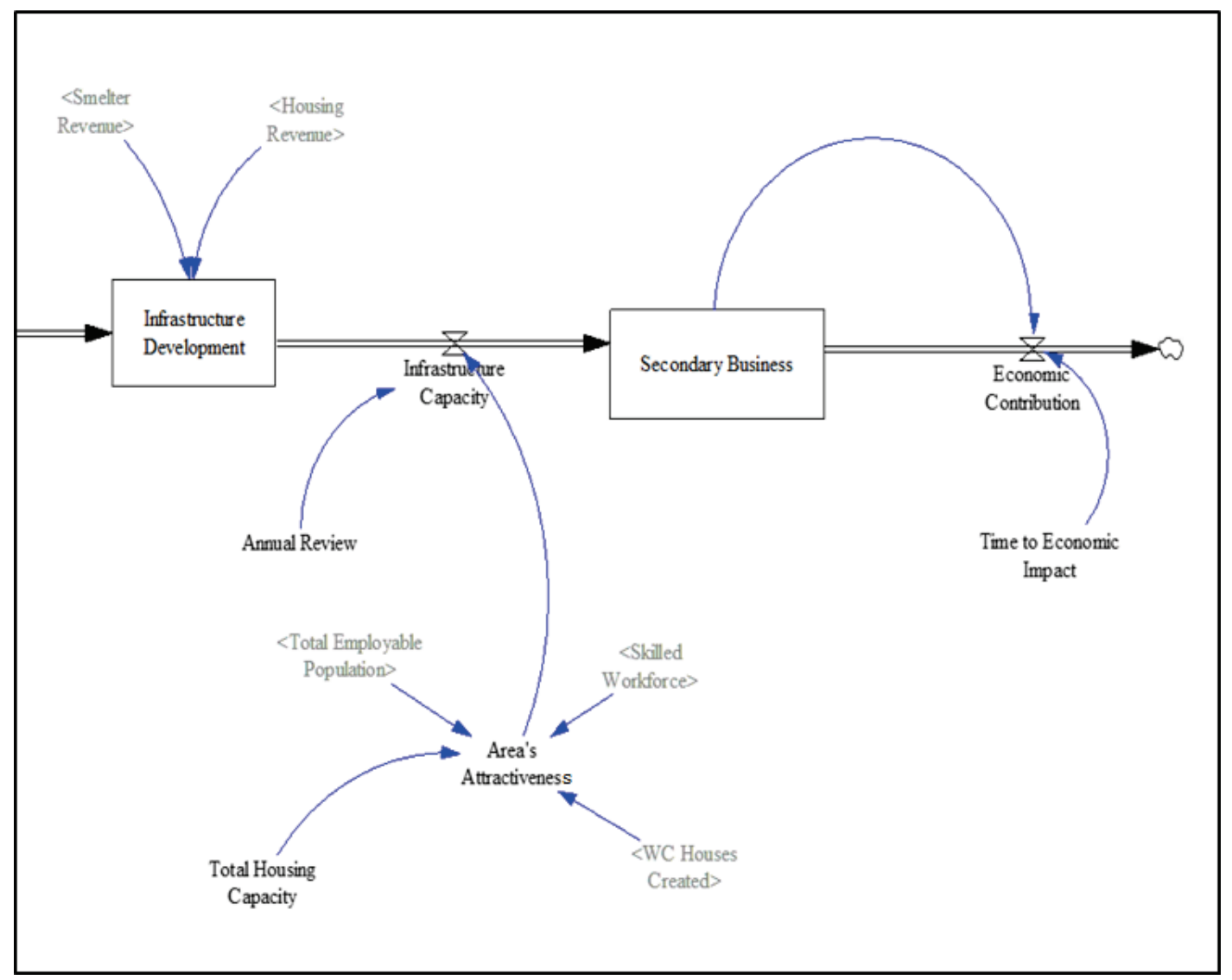

Figure 5: Stock flow logic for infrastructure development

By evaluating the number of skills required vs the number of employable people, and doing the same with available land capacity vs land used for housing development, an index of the area's attractiveness is calculated. The value of this index determines the outcome of the 'infrastructure development' stock and the extent of the inflow into the 'secondary business' stock. The variables that influence the 'area's attractiveness' and their logical links are illustrated in the causes treediagram in Figure 6.

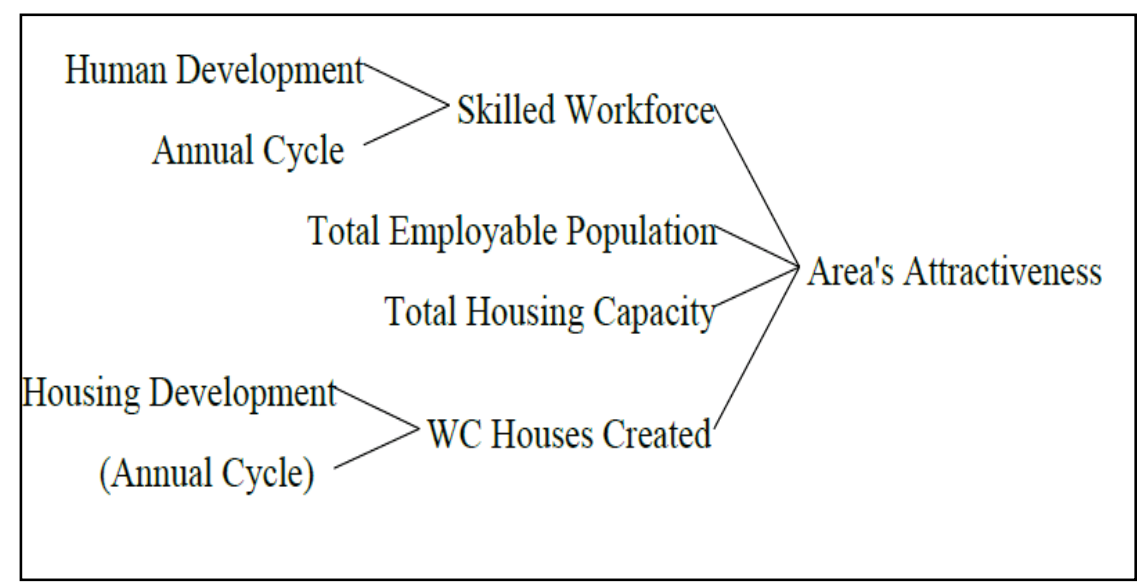

Figure 6: Causes tree-diagram describing the area's attractiveness

In their work on the relative attractiveness of investment in mineral exploration, O'Regan et al. [24] find that a number of micro-level variables (such as per unit cost) act as reinforcing elements in a causal loop that describes the dynamic behaviour of a mining sub-system. In a similar evaluation of 
the relative attractiveness of Ireland as a mining location, O'Regan et al. [24] find that attractiveness is not only dependent on the geology, but on other international markets and marketing strategies employed by competing countries. The construction of the current system dynamics model takes this point into consideration; however, it limits the variables determining the 'area's attractiveness' to housing land capacity and employment capacity. The reason for this position is that employment (a consequence of business activity) and human settlement (housing) are considered sufficient to give an indication of the attractiveness of an area to business and critical skills in South Africa. All the simulation results presented in the next section are for the manganese mining case study environment described previously. The detailed endogenous and exogenous parameter values used in the model are described in more detail in the work of Maluleke [19].

\section{RESULTS PRESENTATION AND ANALYSIS}

The system dynamics model simulation results for the manganese mining case study demonstrate a fluid relationship between infrastructure development, the attractiveness of an area, and economic contribution. The results discussed in this section include the Monte Carlo analysis performed within the system dynamics modelling environment. Figure 7 demonstrates that the relative attractiveness of the area will change over time due to saturation in occupied land and unavailability of a skilled workforce. The results also highlight that policies required to encourage industrial growth can sometimes be compromised by the need to deal with social pressures - for instance, to provide land for housing.

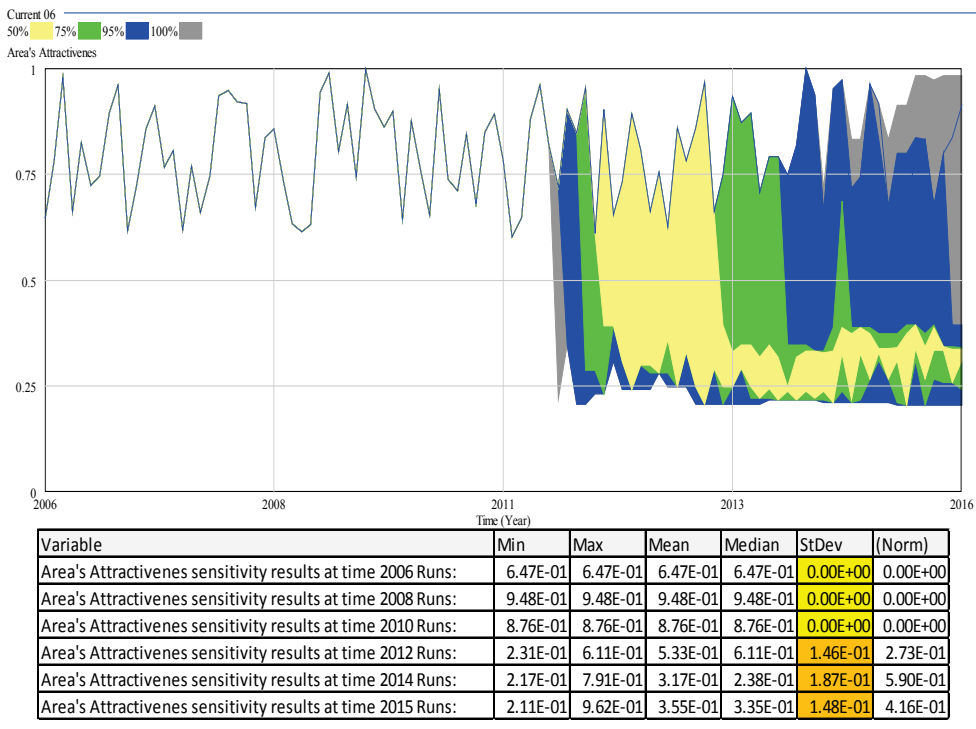

Figure 7: Multivariate sensitivity of attractiveness index in the JTG region

The uncertainty of the 'area's attractiveness', as illustrated by the shaded area of the graph in Figure 7, can be corrected by making unpopular decisions such as limiting occupation of prime land for domestic purposes and prioritising use of this land for industrial purposes. In the case of the JTG region, mining companies often incur massive costs in moving communities that are already placed in areas that host proven mineral reserves beneath their surface. This often happens as a consequence of improper spatial planning and unplanned occupation of land.

The graph in Figure 8 highlights the outcome of the Monte Carlo sensitivity analysis for the economic infrastructure capacity contribution in South African Rands for the manganese mining case study. The graph illustrates a similar pattern of uncertainty in contribution from 2011 to the results presented in Figure 7, which further illustrates the influence of the 'area's attractiveness' factor on infrastructure development. 


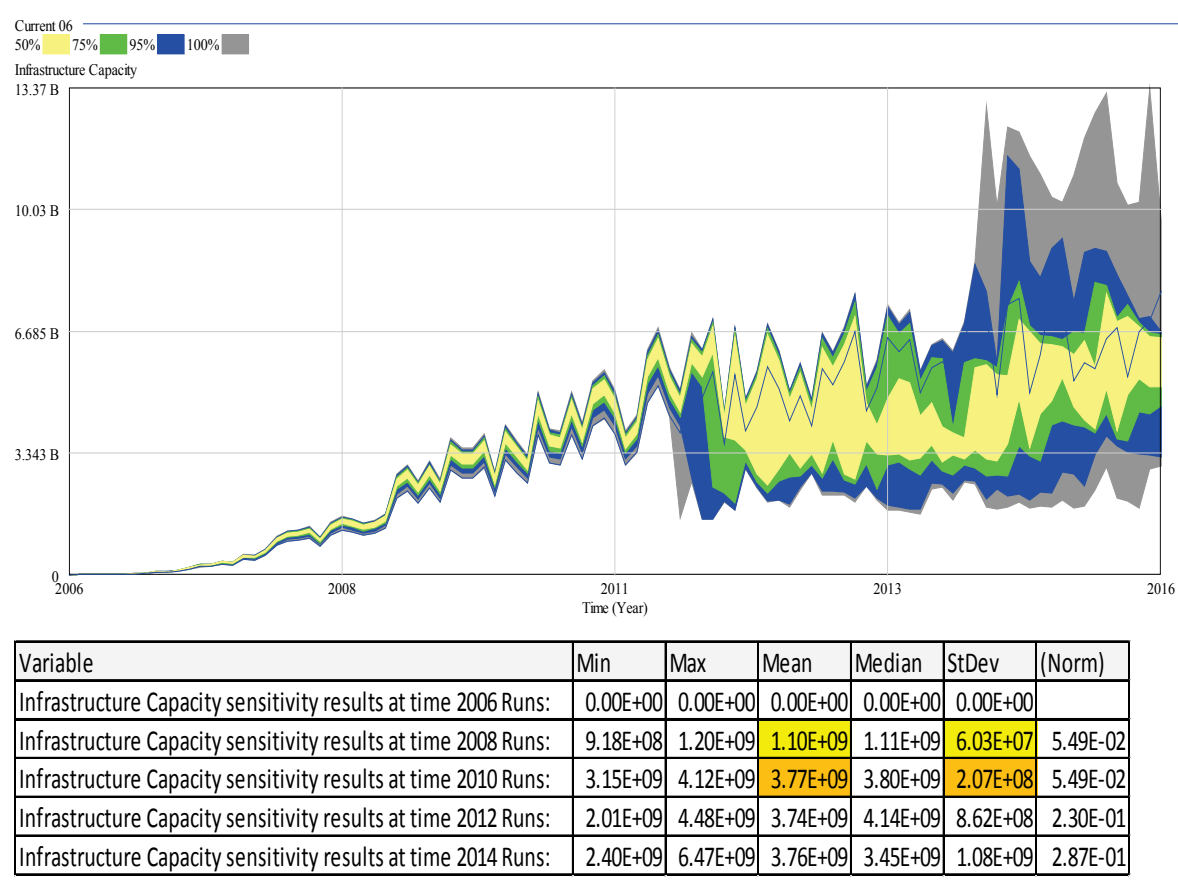

Figure 8: Multivariate sensitivity on infrastructure development

The Monte Carlo results illustrated in Figure 8 indicate that the development of infrastructure capacity, based on beneficiation economy, is certain to grow rapidly in the beginning (as is the case from 2006 to 2011). However, over time it becomes less robust and sensitive (as indicated by the fluctuations from 2011 to 2016) to variation in input costs and market prices. The results of the Monte Carlo analysis on the 'area's attractiveness' have demonstrated that, similar to the findings of Graham et al. [14], variables that make an area attractive at the beginning, such as high rates of employment and housing developments, can lead to the eventual replacement of labour with capital. Inadequate investment in infrastructure could create bottlenecks, and opportunities to promote economic growth could be missed [28].

The conclusion of Holtz-Eakin et al. [16] that public capital injection is the source of intensive economic growth - provided that there is the presence of private capital - supports the view of Perkins et al. [25]. An integrated approach to the mine life cycle and economic development of the region is thus required, as indicated by some of the simulation results presented here. As Ramokgopa et al. [27] find, economic infrastructure is generally created for the purpose of supporting other economic activities in the mid- to long term. Similarly, Munnell [21] has found that, on balance, public capital investment stimulates private investment.

\section{CONCLUSIONS}

The system dynamics model simulation focused on the endogenous variables that drive the performance of the socio-economic system and on how these are affected by changes in the external environment (represented by a selection of exogenous variables). The causal loop diagram in Figure 4 illustrated the system level relationship between elements of economic infrastructure, mining activities, and community social development in relation to sustainable development in a miningdriven economy. The causal relationship between variables affecting mining activities and infrastructure development is complex, and could take a long time to monitor in real life. As Fowler [12] also found, predicting a future scenario through a system dynamics model simulation can therefore provide foresight into system behaviour. The research has established that the attractiveness of the area for infrastructure development and economic growth does not follow a linear relationship with the revenues generated in primary business activities such as mining. Instead, it requires that other factors - such as land capacity, human skills development, and migration patterns - remain viable. In his work in modelling managerial behaviour, Sterman [34] also argues that efficacy and decision strategies lie crucially in the action between decisions and changes in the environment that condition future decisions. 
Munnell [21] argues, however, that the impact of infrastructure investment on economic growth might not be seen in the same year that the investment is made. Congruent with Munnell's [21] view, this research has also established that the high cost of input required in beneficiation processes implicitly carries the necessary potential to stimulate alternative investment in support infrastructure, such as concentrated solar plants. As Nakedi [22] found, the Northern Cape is endowed with long periods of sun radiation - up to 2700 hours per year. Such infrastructure could become the vehicle that supports economic growth and job opportunities in the long term. As O'Regan et al. [24] find, many of the dynamics in complex systems arise from the delayed feedback between decision points, in particular when such feedback crosses the system (organisational) boundary. A decision to invest in infrastructure cannot be based on short-term benefits; instead, to achieve a long-term impact on socio-economic development, tough investment decisions may be required upfront. This is also partially supported by some of the simulation results presented in this paper.

\section{RECOMMENDATIONS FOR FUTURE RESEARCH}

The system boundary defined for the research has left out variables from the JTG region's broad sectors, such as iron ore mining, agriculture, major upgrades of the rail logistics infrastructure [35], and rollout of 3000MW capacity in solar power plants [7]. The inclusion of these variables in other research might influence the socio-economic system performance and the specific conclusions made. The excluded industries might also influence the dynamics in the housing and infrastructure business sector of that economy and, by implication, the human development dynamics in that area. The inclusion of all the variables not studied in this research is recommended for further research.

\section{REFERENCES}

[1] Aronson, D. 1996. Overview of systems thinking. The thinking page.

[2] Barile, S. \& Saviano, M. 2011. Foundations of systems thinking: The structure-system paradigm. Contributions to theoretical and practical advances in management: A viable systems approach (VSA). ASVSA, Associazione per la Ricerca Sui Sistemi Vitali. International Printing, 1-24.

[3] Barlas, Y. 1996. Formal aspects of model validity and validation in system dynamics. System Dynamics Review, 12(3), pp. 183-210.

[4] Cabrera, D., Colosi, L. \& Lobdell, C. 2008. Systems thinking. Evaluation and program planning, 31(3), pp. 299-310.

[5] Davis, J.P., Eisenhardt, K.M. \& Bingham, C.B. 2007. Developing theory through simulation methods. Academy of Management Review, 32(2), pp. 480-499.

[6] DME. 2004. The Minerals and Petroleum Resources Development Act No. 28 of 2002. Website: http: //www.Info@gov.org.za. [Accessed 05 November 2009]

[7] DoE. 2011. Integrated resource plan for electricity 2010 - 2030. Final Report Rev 2. Website: http: / /www.energy.org.za. [Accessed on 12 May 2012]

[8] Esfahani, H.S. \& Ramirez, M.T. 2003. Institutions, infrastructure and economic growth. Journal of Development Economics, 70, pp. 443-477.

[9] Etienne, A.J.A. 2010. Modelling as persuasion: The impact of group model building on attitudes and behaviour, John Wiley \& Sons: Netherlands.

[10] Forrester, J.W. 1971. Counterintuitive behaviour of social systems, Theory and Decision, 2(2), pp. 109140.

[11] Forrester, J.W. 1969. Urban dynamics, Cambridge, MA: MIT Press.

[12] Fowler, A. 2003. Systems modelling, simulation and the dynamics of strategy, Journal of Business Research, 56, pp.135-144..

[13] Franklin, M.M. 2005. Applying modelling 1956 and simulation as part of business process improvement for complex mining logistics, A Pen State and Colorado School of Mines Conference on Business Process Improvement in the Extractive Industry, Denver, CO.

[14] Graham, A.K. \& Senge, P.M. 1980. Along-wave hypothesis of innovation. Technological Forecasting and Social Change, 17, pp. 283-311.

[15] Harrison, J.R., Carroll, G.R. \& Carley, K.M. 2007. Simulation modelling in organisational and management research, Academy of Management Review, 32(4), pp. 1229-1245.

[16] Holtz-Eakin, D. \& Schwartz, A.E. 1995. Infrastructure in a structural model for economic growth, Regional Science and Urban Economics, 25(2), pp. 131-151., pp. .

[17] Kleijnen, J.P.C. 1993. Verification and validation of simulation models: Theory and methodology. European Journal of Operational Research, 82, pp.145-162. pp.

[18] Kramer, N.J.T.A. \& De Smit, J. 1977. Systems thinking. Leiden: Martinus.

[19] Maluleke, G.T. 2014. A systems approach to sustainable development through resource beneficiation: A case for system dynamics modelling. PhD thesis, University of Pretoria.

[20] Meyer, D. \& Page, C. 2005. Applied research design for business and management. McGraw-Hill Higher Education. 
[21] Munnell, A.H. 1992. Infrastructure investment and economic growth: Economic watch, Journal of Economic Perspectives, 6(4), pp.189-198..

[22] Nakedi, A. 2011. The role of concentrating solar power and solar PV in renewables, COP 17 Site Events. Durban, South Africa.

[23] Oliva, R. 2002. Model calibration as a testing strategy for system dynamics models: Decision aiding, European Journal of Operational Research, 151, pp. 552-568.

[24] O'Regan, B. \& Moles, R. 2000. An insight into system dynamics method: A case study in the dynamics of international minerals investment, Environmental Model and Software, 16 , pp. 339-350. .

[25] Perkins, P., Fedderke, J. \& Luiz, J. 2005. An analysis of economic infrastructure investment in South Africa, South African Journal of Economics, 73(2), pp. 211-227.

[26] Pienaar, P.C. \& Smith, W.F.P. 1992. A case study of the production of high-grade manganese sinter from low-grade Mamatwan manganese ore. $6^{\text {th }}$ International Ferroalloys Congress (1), Johannesburg: SAIM.

[27] Ramokgopa, B. \& Pietersen, E. 2008. The tariff history. Website: http://www.nersa.org.za. [Accessed on 05 January 2012]

[28] Repenning, N.P. 2003. Selling system dynamics to (other) social scientists, System Dynamics Review, 19(4), pp. 303-327.

[29] Roos, A.W. 2000. Knowledge management in learning organisations based on the systems dynamics approach, Working Paper, Fachhochoschule Stuttgart.

[30] Saeed, K. 2010. Economic development, creative destruction and urban dynamics: A proposal for rethinking development agendas. The $28^{\text {th }}$ International System Dynamics Conference, Seoul, Korea.

[31] SAMI. 2009. The South African Mineral Industry. Director: Mineral Economics. Mineral Centre, Pretoria, South Africa.

[32] SARB. 2012. Quarterly bulletin, September releases No 465. Website: http://www.reservebank.co.za. [Accessed 20 September 2013]

[33] Senge, P.M. \& Suzuki, J. 1994. The fifth discipline: The art and practice of the learning organization. New York: Currency Doubleday.

[34] Sterman, J.D. 1989. Sterman, J. D. (1989). Modeling managerial behavior: Misperceptions of feedback in a dynamic decision making experiment. Management science, 35(3), 321-339

[35] Transnet. 2012. Rail Charges. Website: http://www.transnet.co.za. [Accessed on 10 June 2012]

[36] Vensim. 2010. Website: http:www.vensim.com. [Accessed on 10 March 2010]

[37] Weinberg, G.M. 2001. An introduction to general systems thinking, Silver anniversary edition, New York: Dorset House Publishing. 